\title{
HOMESCHOOLING IN POLAND, THE CZECH REPUBLIC AND SLOVAKIA
}

\author{
Ivana Rochovská \\ Catholic University in Ružomberok, Slovakia \\ Piotr Mazur \\ The State School of Higher Education in Chelm, Poland \\ Eva Dolinská \\ Catholic University in Ružomberok, Slovakia
}

\begin{abstract}
This research reveals the issue of homeschooling. It deals with homeschooling in post-communist countries with a similar tradition of the education system - Poland, the Czech Republic, and Slovakia. It defined the basic concepts associated with homeschooling and, through both quantitative and qualitative research, a questionnaire with 78 parents of homeschooled children and a document review compared the homeschooling system in these countries. On the basis of the research findings, it could be stated similar homeschooling conditions provided in each country, differing mainly in the student's age aimed to. Unschooling, one of homeschooling types, a curriculum-free philosophy, has not been applied and recognized as a legitimate form of education in any of these countries yet. Many parents have been experimenting with educating their children at home though and would welcome it to be legal.
\end{abstract}

Keywords: homeschooling, individual education, qualitative research, unschooling.

\section{Introduction}

The origins of homeschooling stem from a criticism of the classical school movement. ${ }^{1}$ Changes in the traditional understanding of the education system and pedagogy have taken place since Rousseau (1962), as part of the reform of the pedagogical movement.

The origins of homeschooling go back to the United States, in the 1970s and 1980s. The stimulus was a growing dissatisfaction with the classical public education system. Among significant proponents of homeschooling were Holt (1964, 1967, 2003), Moore, R. S. and Moore, D. N. (1975), Griffith (1997), and Gaither (2008).

Gray (2013) described his experience gained during the long-term study of children's self-education, starting with the self-education of hunter-gatherers in primitive tribes, as well as the self-education of children at Sudbury Valley School, in Massachusetts. Indeed, the researcher claimed that children from the culture of hunter-gatherers became successful adults without schooling.

A great uproar among teachers, concerning the existence of the school, was awoken

1 The purpose of this research is not to expand or deepen these criticisms, nor to put homeschooling into opposition with a classical education system. 
by the work of Illich (2002). The researcher declared his conviction to the separation between the school and society. According to the researcher, the school fulfilled an indoctrination role, the learners could not decide freely what and how to learn, their individual creativity was restrained, the learners were divided into the successful and the unsuccessful ones from the lowest grades, separated from life, etc., with its content (Illich, 2002).

Researchers in the United States find that "homeschooled students score as well as or better than their public school peers in college entrance examinations" (Murphy, 2014, p. 21; Cogan, 2010; Ray \& Weller, 2003). According to Krajčovičová and Krajčovič (2015), Slovak homeschooled students achieved very good results in their final examination at the end of the school year.

Homeschooling has gradually become rooted in the legislation of European countries, including Poland, the Czech Republic, and Slovakia. The most commonly used term in relation to the research issue is homeschooling. We can find individual education rooted in Slovak and Czech legislation, homeschooling as one of its forms, whereas the term home education is used in Polish legislative documents.

\section{Research Problem}

The research problem is a question, how individual (home) education takes place in these countries, and if there is a difference between the options for providing homeschooling in Poland, the Czech Republic and Slovakia. The aim of the research was to compare the education systems of these countries, in terms of the options for providing homeschooling, and to find out the opinions of the parents of homeschooled children related to homeschooling in these selected countries. This comparison can be useful for professionals who deal with (not only) homeschooling in these countries.

Research Questions (RQ):

1. In which country was the homeschooling of learners first allowed by law, and which was the last to allow it?

2. Is homeschooling for learners in these countries limited to a certain age group of learners?

3. How is it possible to apply for a learner's homeschooling?

4. Did parents have any difficulty in approving their child's individual (home) education?

5. How did they choose school for their child?

6. How did they choose a guarantor for their child?

7. Which methods and forms of education are chosen by parents?

8. How was the compulsory examination of children going?

\section{Research Methodology}

\section{General Background}

This research was carried out between September 2018 and June 2019. It was a part of one larger project entitled "Individual Education in the V4 Countries - A Comparative Research Study” (Rochovská \& Mazur, 2019). In this larger research project, quantitative 
research methods (a questionnaire, an interview) and qualitative research methods (an interview, a method of examining documents) were used to find out the conditions for homeschooling in V4 countries.

\section{Sample}

The research sample was assured by the selection available. Respondents were contacted online via social networks. The research sample was created only by the respondents who were willing to participate in the research. 78 parents of homeschooled children were involved in the research: 30 from Poland (PL), 27 from the Czech Republic (CZ), and 21 from Slovakia (SK). The respondents were briefed on the aim of the research, they voluntarily participated in the research, and they were promised to remain anonymous.

The research sample consisted of $10.26 \%$ men and $89.74 \%$ women. The majority of respondents $(52.56 \%)$ were in the age category $31-40$ years (Table 1$)$.

Table 1. The age of the respondents (\%).

\begin{tabular}{lrrrrr}
\hline Age (years) & $\mathbf{2 1 - 3 0}$ & $\mathbf{3 1 - 4 0}$ & $\mathbf{4 1 - 5 0}$ & $\mathbf{5 1 - 6 0}$ & No response \\
\hline \% resp. & 3.85 & 52.56 & 34.62 & 3.85 & 0.00 \\
PL & 0 & 46.67 & 40.00 & 10.00 & 3.33 \\
CZ & 3.70 & 59.26 & 37.04 & 0 & 0.00 \\
SK & 11.11 & 77.78 & 27.78 & 0 & 0.00 \\
\hline
\end{tabular}

Most of the respondents from each country home-schooled one child, some of them educated two children at home, and exceptionally some of them did three or four children (Table 2). Their age was from 5 to 19 years.

Table 2. Number of respondents' children in home education.

\begin{tabular}{lllllll}
\hline $\begin{array}{l}\text { Number } \\
\text { children }\end{array}$ & of & PL & \multicolumn{3}{c}{ CZ } & \multicolumn{3}{c}{ SK } & \\
\cline { 2 - 7 } 1 & $\boldsymbol{N}$ & $\%$ & $\boldsymbol{N}$ & $\%$ & $\boldsymbol{N}$ & $\%$ \\
2 & 23 & 76.67 & 16 & 59.26 & 13 & 72.22 \\
3 & 4 & 13.33 & 7 & 25.93 & 7 & 38.89 \\
4 & 1 & 3.33 & 4 & 14.81 & 0 & 0.00 \\
No answer & 1 & 3.33 & 0 & 0.00 & 0 & 0.00 \\
Total & 1 & 6.67 & 0 & 0.00 & 1 & 5.56 \\
\hline
\end{tabular}


More than half of the respondents from each country said they had no pedagogical education. $34.67 \%$ of them said they had pedagogical education (Table 3 ). The majority of them said they had teaching practice shorter than 5 years.

Table 3. Pedagogical education of the respondents (\%).

\begin{tabular}{|c|c|c|c|c|c|c|c|c|}
\hline \multirow{2}{*}{$\begin{array}{l}\text { Pedagogical } \\
\text { education }\end{array}$} & \multicolumn{2}{|c|}{ PL } & \multicolumn{2}{|c|}{$\mathrm{CZ}$} & \multicolumn{2}{|c|}{ SK } & \multicolumn{2}{|c|}{ Total } \\
\hline & $n$ & $\%$ & $n$ & $\%$ & $n$ & $\%$ & $n$ & $\%$ \\
\hline Yes & 9 & 30.00 & 7 & 25.93 & 10 & 55.56 & 26 & 34.67 \\
\hline No & 19 & 63.33 & 19 & 70.37 & 10 & 55.6 & 48 & 64.00 \\
\hline Unfinished & 1 & 3.33 & 1 & 3.70 & 0 & 0.00 & 2 & 2.67 \\
\hline $\begin{array}{l}\text { Other } \\
\text { response }\end{array}$ & 1 & 3.33 & 0 & 0.00 & 1 & 5.56 & 2 & 2.67 \\
\hline
\end{tabular}

The research sample also consisted of three main documents:

1. Act on Education System from 19th December 2016 (Ustawa z dnia 14 grudnia 2016 roku - Prawo oświatowe) in Poland.

2. Act No. 561/2004 Coll., on Pre-school, Basic, Secondary, Tertiary Professional and Other Education (the Education Act), in the Czech Republic.

3. Act No. 245/2008 Coll. on Upbringing and Education (The School Act) in Slovakia.

\section{Instrument and Procedures}

During the research, both the method of an online structured questionnaire and the method of examining documents were used. A questionnaire was used to find out the opinions of the respondents. It contained 10 open-ended questions. They concerned the number of children in the home (individual) education, their age, difficulties in approval of home (individual) education of their child, the selection of school, the selection of a guarantor with required (pedagogical) education, methods and forms of the education, the compulsory examination of their child, and potential difficulties in the examination. The respondents answered the questions electronically (online through social groups related to home education). 


\section{Data Analysis}

The data analysis was both quantitative and qualitative (descriptive). The legislative anchoring of individual education (homeschooling) in selected countries was described. The concepts associated with established research questions RQ1, RQ2, RQ3, RQ4, RQ6, and RQ8 are in bold.

Respondents' responses obtained through a questionnaire were categorized. Chisquare goodness of fit test was used to answer the research questions RQ4, RQ5, RQ6, RQ7, and RQ8.

\section{Research Results}

\section{Legislative Anchoring of a Home Education in Poland}

In Poland, home education has been allowed since 1991, as the first of these countries (RQ1). The School Educational Act of 1991 allowed for home education, but parents had to request permission from the head of a public or a non-public nursery school (ISCED 0), a primary school (ISCED 1, 2), a grammar school or a secondary school (ISCED 3) (RQ2), to which the child was accepted. The parent can make a decision to allow the child to fulfil an educational duty outside of the nursery school, pre-school section or other form of pre-school education, or outside of the school (RQ3).

This decision may be issued before the beginning of the school year, or during the school year. Along with an application for fulfilling the compulsory school attendance outside of the school, it is necessary to add the opinion of pedagogical-psychological counseling, a parental declaration about the provision of conditions that will enable the child to implement the curriculum valid for the given stage of education, the obligation for parents to provide co-operation in each school year to subject the child to examination and classification (RQ4, RQ8).

\section{Legislative Anchoring of Individual Education in the Czech Republic}

In the Czech Republic, since 2005 (RQ1) an individual education is an equivalent form of fulfilling the compulsory school attendance at the first stage of primary school ISCED 1 (RQ2), since 2016 (RQ1) at the second stage of primary school ISCED 2 (RQ2), and should be permitted at all elementary schools. Permission for individual education is decided by the headmaster of the school, where the learner has been accepted to attend compulsory schooling, based on the written request from the legal guardian of the learner (RQ3). This application must include the reasons for the individual education of the learner; a description of the spatial and material-technical provision of the education and conditions for the health protection of the individually educated learner, documents certifying the fulfilment of the education of the person, who will educate the learner individually, a list of textbooks and teaching texts, which will be used during the teaching and finally the opinion of a school counselling facility (RQ4).

The head allows individual education in the case where there are serious reasons for individual education, if sufficient conditions are ensured, in particular material ones and 
those concerning the learner's health and safety are ensured (RQ4), if the person, who is going to educate the learner, has at least a secondary education with a maturity exam ISCED 3 (in the case of a learner at the first stage of Primary School, ISCED 1) or higher education ISCED 5 (in the case of a learner at the second stage, ISCED 2) (RQ6), and if the appropriate textbooks and teaching texts will be ensured. Every half year, an individually educated learner takes exams from the relevant school subject at the school where he was accepted to attend his compulsory school attendance (RQ8).

\section{The Legislative Anchoring of Individual Education in Slovakia}

From 2008 (RQ1), individual education is enacted in Slovakia, too (the last of these countries). The law distinguishes between two forms of individual education, videlicet, individual education for health reasons and for non-health reasons. In the meantime, homeschooling as a form of individual education is allowed only at the first stage of primary school level ISCED 1 (RQ2), by a person, who meets the qualification requirements of higher education of the second stage (ISCED 5), established for teachers on the first stage of Primary School (RQ6).

The child is enrolled in the primary school chosen by his/her legal guardian, or private or public. It is a free choice where to become a student, not depending on a place of residence).

An application for individual education is submitted by the child's legal guardian (or a learner of an adult age) to the headmaster of the school, to which the learner has been accepted. This application should include: reasons for authorising individual education; an individual education program (home-school plan); a description of the spatial and materialtechnical and health conditions of the individually educated learner; the name and surname of the person/teacher, who will carry out the individual education of the learner, to whom an individual education will be permitted, and their documentation on the fulfilling of the necessary qualification requirements; a list of textbooks and teaching texts, which will be used in the individual education of the learner (RQ4).

A learner, who has been granted an individual education, takes examination in the Primary School where enrolled. The low requires assessment every half year (RQ8) therefore homeschooled students must be evaluated semi-annually. Based on the annual results of the exam the school issues a certificate.

\section{Number of Home Educated Children}

In 2018 in Poland, 11466 children were home educated, which is $0.3 \%$ of all learners in the country who are legally allowed home education. In the Czech Republic, there were 3232 children individually educated, which is $0.3 \%$ of all learners in the country who are legally allowed individual education. In Slovakia, there were 579 children individually educated, which is $0.3 \%$ of all learners in the country who are legally allowed individual education. An overview of individually (home) educated learners in 2014-2018 is presented in the Table 4. 
Table 4. An overview of individually (home) educated children. ${ }^{2}$

\begin{tabular}{|c|c|c|c|c|}
\hline \multirow{2}{*}{ Year } & \multicolumn{4}{|c|}{ Number of individually (home) educated children } \\
\hline & Poland (PL) & $\begin{array}{l}\text { The Czech } \\
\text { (CZ) }\end{array}$ & Republic & Slovakia (SK) \\
\hline 2014 & 2669 & 1038 & & 70 \\
\hline 2015 & 7641 & 1339 & & 95 \\
\hline 2016 & 11251 & 2067 & & 149 \\
\hline 2017 & 14051 & 2591 & & 481 \\
\hline 2018 & 11466 & 3232 & & 579 \\
\hline
\end{tabular}

Answers to the Research Questions (obtained through a questionnaire)

Table 5 shows the respondents' difficulties in approving child's individual (home) education (RQ4).

Table 5. Difficulties in approving child's individual (home) education.

\begin{tabular}{lllllllll}
\hline Respondents' responses & PL & & CZ & & SK & \multicolumn{3}{c}{ Total } \\
\hline & $n$ & $\%$ & $n$ & $\%$ & $n$ & $\%$ & $n$ & $\%$ \\
No & 4 & 13.33 & 15 & 55.56 & 11 & 52.38 & 30 & 38.46 \\
Yes & 0 & 0 & 1 & 3.70 & 1 & 4.76 & 2 & 2.56 \\
Problems with PPP & 5 & 16.67 & 0 & 0 & 0 & 0 & 5 & 6.41 \\
School unwillingness & 1 & 3.33 & 0 & 0 & 0 & 0 & 1 & 1.28 \\
No answer & 20 & 66.67 & 11 & 40.74 & 9 & 42.86 & 40 & 51.28 \\
\hline
\end{tabular}

Note: According to the current regulations in Poland, children studying at home may be assigned only to the school in the province they live in. To obtain a permit for homeschooling the opinion from the pedagogicalpsychological counselling (PPP) is required. Therefore, the problems with PPP were mentioned only by the respondents from Poland.

The respondents' responses were compared through Chi-square goodness of fit. There was a statistically significant difference $\left(\chi^{2}(3)=59.895, p<.0001\right)$ between the respondents' responses. Most respondents (38.46\%) said they had no problems approving the application for individual (home) education.

Table 6 shows the reasons for winning School choice (RQ5).

2 The table does not include children enrolled abroad and children with special educational needs that have reduced attendance or social leave, etc. 
Table 6. School selection criteria.

\begin{tabular}{|c|c|c|c|c|c|c|c|c|}
\hline Respondents' responses & PL & & $\mathbf{C Z}$ & & SK & & To & \\
\hline & $n$ & $\%$ & $n$ & $\%$ & $n$ & $\%$ & $n$ & $\%$ \\
\hline School's experience of home education & 20 & 42.55 & 10 & 27.78 & 9 & 37.50 & 39 & 36.45 \\
\hline Form of compulsory examination & 7 & 14.89 & 4 & 11.11 & 7 & 29.17 & 18 & 16.82 \\
\hline Director and school approach & 5 & 10.64 & 3 & 8.33 & 1 & 4.17 & 9 & 8.41 \\
\hline $\begin{array}{l}\text { Recommendation of family and } \\
\text { acquaintances }\end{array}$ & 3 & 6.38 & 6 & 16.67 & 0 & 0.00 & 9 & 8.41 \\
\hline Place of residence & 1 & 2.13 & 5 & 13.89 & 0 & 0.00 & 6 & 5.61 \\
\hline Flexibility of testing dates & 3 & 6.38 & 2 & 5.56 & 1 & 4.17 & 6 & 5.61 \\
\hline Access to children & 2 & 4.26 & 0 & 0.00 & 2 & 8.33 & 4 & 3.74 \\
\hline $\begin{array}{l}\text { Recommendation of parents of other } \\
\text { children in home education }\end{array}$ & 0 & 0.00 & 3 & 8.33 & 0 & 0.00 & 3 & 2.80 \\
\hline $\begin{array}{l}\text { Other recommendations (e.g. Home } \\
\text { Education Associations, Home } \\
\text { Education Coordinators) }\end{array}$ & 3 & 6.38 & 0 & 0.00 & 0 & 0.00 & 3 & 2.80 \\
\hline Others & 3 & 6.38 & 3 & 8.33 & 4 & 16.67 & 10 & 9.35 \\
\hline
\end{tabular}

The respondents' responses were compared through Chi-square goodness of fit. There was a statistically significant difference $\left(\chi^{2}(9)=99.822, p<.0001\right)$ between the respondents' responses. According to the respondents' responses, the choice of school depended mainly on the school's experience of home education (36.45\%).

Table 7 shows criteria used to choose a guarantor for their child (RQ6).

Table 7. Guarantor selection criteria.

\begin{tabular}{lllllllll}
\hline Respondents' responses & PL & & CZ & & SK & \multicolumn{3}{c}{ Total } \\
\hline \multirow{2}{*}{ No criterion } & $\boldsymbol{n}$ & $\mathbf{\%}$ & $\boldsymbol{n}$ & $\mathbf{\%}$ & $\boldsymbol{n}$ & $\%$ & $\boldsymbol{n}$ & $\%$ \\
Family & 29 & 96.66 & 21 & 77.77 & 9 & 42.86 & 59 & 75.64 \\
Acquaintances & 0 & 0 & 4 & 14.81 & 1 & 4.76 & 5 & 6.41 \\
Guarantor willingness & 0 & 0 & 1 & 3.7 & 3 & 14.29 & 4 & 5.13 \\
Formal guarantor (with diploma) & 0 & 0 & 0 & 0 & 3 & 14.29 & 3 & 3.85 \\
Others & 0 & 0 & 0 & 0 & 2 & 9.52 & 2 & 2.56 \\
\hline & 1 & 3.33 & 1 & 3.7 & 3 & 14.29 & 5 & 6.41 \\
\hline
\end{tabular}

Note: In Poland, it is not mandatory by law to have a guarantor.

The respondents' responses were compared through Chi-square goodness of fit. There was a statistically significant difference $\left(\chi^{2}(5)=195.846, p<.0001\right)$ between the respondents' responses. According to respondents' responses, the majority of them $(75.64 \%)$ had no criterion when choosing a guarantor for their child. 
The methods and forms of education mentioned by respondents (RQ7) were grouped into categories, with no didactic method and form structure applied, but retained as they were reported by the respondents (Table 8).

Table 8. Methods and forms selection.

\begin{tabular}{|c|c|c|c|c|c|c|c|c|}
\hline \multirow{2}{*}{ Respondents' responses } & \multicolumn{2}{|c|}{ PL } & \multicolumn{2}{|c|}{$\mathbf{C Z}$} & \multirow{2}{*}{$\begin{array}{l}\text { SK } \\
n\end{array}$} & \multicolumn{3}{|c|}{ Total } \\
\hline & $n$ & $\%$ & $n$ & $\%$ & & $\%$ & $n$ & $\%$ \\
\hline Unschooling & 7 & 9.86 & 9 & 18.75 & 8 & 15.69 & 24 & 14.12 \\
\hline Working with a textbook & 9 & 12.68 & 4 & 8.33 & 2 & 3.92 & 15 & 8.82 \\
\hline Reading and speaking & 8 & 11.27 & 1 & 2.08 & 5 & 9.80 & 14 & 8.24 \\
\hline Projects & 6 & 8.45 & 2 & 4.17 & 4 & 7.84 & 12 & 7.06 \\
\hline Working with a workbook & 3 & 4.23 & 3 & 6.25 & 3 & 5.88 & 9 & 5.29 \\
\hline Montessori & 2 & 2.82 & 2 & 4.17 & 5 & 9.80 & 9 & 5.29 \\
\hline Excursions & 6 & 8.45 & 1 & 2.08 & 2 & 3.92 & 9 & 5.29 \\
\hline Plays & 4 & 5.63 & 2 & 4.17 & 2 & 3.92 & 8 & 4.71 \\
\hline $\begin{array}{l}\text { Online form (e.g. Khan } \\
\text { Academy) }\end{array}$ & 3 & 4.23 & 3 & 6.25 & 2 & 3.92 & 8 & 4.71 \\
\hline Experiential learning & 3 & 4.23 & 1 & 2.08 & 4 & 7.84 & 8 & 4.71 \\
\hline Learning outside & 3 & 4.23 & 1 & 2.08 & 2 & 3.92 & 6 & 3.53 \\
\hline Experiments, discovering & 2 & 2.82 & 2 & 4.17 & 2 & 3.92 & 6 & 3.53 \\
\hline Internet & 3 & 4.23 & 0 & 0.00 & 1 & 1.96 & 4 & 2.35 \\
\hline Interest activities & 2 & 2.82 & 1 & 2.08 & 1 & 1.96 & 4 & 2.35 \\
\hline Watching movies, videos & 2 & 2.82 & 2 & 4.17 & 0 & 0.00 & 4 & 2.35 \\
\hline $\begin{array}{l}\text { Community schools, } \\
\text { groups }\end{array}$ & 1 & 1.41 & 0 & 0.00 & 2 & 3.92 & 3 & 1.76 \\
\hline Portfolio creation & 0 & 0.00 & 2 & 4.17 & 0 & 0.00 & 2 & 1.18 \\
\hline Lapbooks & 1 & 1.41 & 1 & 2.08 & 0 & 0.00 & 2 & 1.18 \\
\hline Others & 6 & 8.45 & 11 & 22.92 & 6 & 11.76 & 23 & 13.53 \\
\hline
\end{tabular}

The respondents' responses were compared through Chi-square goodness of fit. There was a statistically significant difference $\left(\chi^{2}(18)=80.656, p<.0001\right)$ between the respondents' responses. According to the respondents, most of them said they practiced unschooling (14.12\%).

Table 9 shows how the compulsory examination of children according to the respondents went (RQ8). 
Table 9. The process of compulsory child examination.

\begin{tabular}{|c|c|c|c|c|c|c|c|c|}
\hline \multirow{2}{*}{ Respondents' responses } & \multicolumn{2}{|c|}{ PL } & \multicolumn{2}{|c|}{$\mathbf{C Z}$} & \multicolumn{2}{|c|}{ SK } & \multicolumn{2}{|c|}{ Total } \\
\hline & $n$ & $\%$ & $n$ & $\%$ & $n$ & $\%$ & $n$ & $\%$ \\
\hline $\begin{array}{l}\text { Satisfaction, without problems } \\
\text { and in a pleasant atmosphere }\end{array}$ & 20 & 47.62 & 17 & 36.17 & 10 & 43.48 & 47 & 41.96 \\
\hline $\begin{array}{l}\text { Oral exam (interview with a } \\
\text { child }\end{array}$ & 8 & 19.05 & 9 & 19.15 & 2 & 8.70 & 19 & 16.96 \\
\hline Written exam (test) & 10 & 23.81 & 7 & 14.89 & 3 & 13.04 & 20 & 17.86 \\
\hline Portfolio presentation & 0 & 0.00 & 7 & 14.89 & 1 & 4.35 & 8 & 7.14 \\
\hline $\begin{array}{l}\text { Sample presentations created } \\
\text { by the child }\end{array}$ & 3 & 7.14 & 1 & 2.13 & 1 & 4.35 & 5 & 4.46 \\
\hline Dissatisfaction & 0 & 0.00 & 4 & 8.51 & 2 & 8.70 & 6 & 5.36 \\
\hline Not yet examined & 0 & 0.00 & 1 & 2.13 & 2 & 8.70 & 3 & 2.68 \\
\hline Others & 1 & 2.38 & 1 & 2.13 & 2 & 8.70 & 4 & 3.57 \\
\hline
\end{tabular}

The respondents' responses were compared through Chi-square goodness of fit. There was a statistically significant difference $\left(\chi^{2}(7)=110.857, p<.0001\right)$ between the respondents' responses. The respondents mostly said that examination was done to their satisfaction, with no problems and in a pleasant atmosphere (41.96\%).

Table 10 shows the difficulties in compulsory child examination (RQ8).

Table 10. Problems in compulsory child examination.

\begin{tabular}{|c|c|c|c|c|c|c|c|c|}
\hline \multirow{2}{*}{$\begin{array}{l}\text { Respondents' } \\
\text { responses }\end{array}$} & \multicolumn{2}{|c|}{ PL } & \multicolumn{2}{|c|}{$\mathbf{C Z}$} & \multicolumn{2}{|l|}{ SK } & \multicolumn{2}{|c|}{ Total } \\
\hline & $n$ & $\%$ & $n$ & $\%$ & $n$ & $\%$ & $n$ & $\%$ \\
\hline $\begin{array}{l}\text { Misunderstanding of } \\
\text { homeschooling by some } \\
\text { teachers }\end{array}$ & 1 & 7.14 & 2 & 22.22 & 4 & 50.00 & 7 & 22.58 \\
\hline $\begin{array}{l}\text { Bad timing / long } \\
\text { waiting / lack of time }\end{array}$ & 4 & 28.57 & 2 & 22.22 & 0 & 0.00 & 6 & 19.35 \\
\hline Nervousness of the child & 1 & 7.14 & 1 & 11.11 & 2 & 25.00 & 4 & 12.90 \\
\hline $\begin{array}{l}\text { Dissatisfaction by the } \\
\text { examiner }\end{array}$ & 2 & 14.29 & 0 & 0.00 & 0 & 0.00 & 2 & 6.45 \\
\hline Others & 6 & 42.86 & 4 & 44.44 & 2 & 25.00 & 12 & 38.71 \\
\hline
\end{tabular}

Most respondents did not encounter difficulties when examined. Respondents who encountered difficulties (Table 10) reported mainly the misunderstanding of homeschooling by some teachers $(22.58 \%)$. The respondents' responses were compared through Chi-square 
goodness of fit. There was not a statistically significant difference $\left(\chi^{2}(4)=9.161, p=.057\right)$ between the respondents' responses.

However, the results could be influenced by the category "Others" that contains some specific answers not added into the previous categories, e.g. "a lot of snow", "the teacher is a strange person".

\section{Discussion}

It can be stated that social conditions, not only in Poland, the Czech Republic and Slovakia, require the adoption of a new educational paradigm, and that is the lifelong learning of all society members, throughout their lives. This should happen not only at the level of formal education in schools, but also at an informal level (in enterprises, state and public administration, interest and civic associations) and informal education (spontaneously happening in work, public and private life).

On the basis of the research findings, it could be stated and confirmed similar homeschooling conditions provided in each country, differing mainly in the student's age aimed to, as mentioned before.

Another difference appeared, in Poland it is not necessary to have a guarantor for a child, while in Czech Republic and Slovakia a guarantor is required (in Slovakia, qualification of teaching in Primary School is obligatory). Nevertheless, homeschooler's parents in Poland (compared to the Czech and Slovak ones), struggle with obtaining a permission from the pedagogical-psychological counselling.

In practice, the Polish, Czech and Slovak homeschooling is quite varied, ranging from unschooling to the strict pursuit of the official school curriculum in the home environment (Kašparová, 2015). Once they find some interesting ideas they want to test, they use an unlimited number of methods for how to implement them.

Based on the presented theoretical origins of this research, the authors cited largely preferred free education and the philosophy of unschooling. In Polish, Czech and Slovak terms, such forms of education are not allowed under the legislation in force. Learners are every half a year (in Slovakia and in the Czech Republic), or once a year (in Poland) undergoing an examination of how they fulfil the compulsory curriculum.

Coming from the theoretical part of this research, it can be said that free schools like Sudbury Valley (Gray, 2003) or Summerhill (Neill, 1960) work efficiently all around the world. In the countries studied so far, schools that apply the philosophy of unschooling are not allowed, although many parents educating their children at home would welcome the possibility of enrolling children in such schools.

Many parents are experimenting with "unschooling" (Table 8). According to research results by Kašparová (2012), there are families in the Czech Republic who already practice the unschooling life strategy, educating their children at home. The situation is similar in Slovakia and Poland (Rochovská \& Mazur, 2019; Giercarz-Borkowska, 2019). Though, if this way educated learners succeed in the half-year and end-of-year examinations at the school they are enrolled in, it is not a problem for any party involved. 


\section{Conclusions}

It has been found that homeschooling in Slovakia is applied by learners at the $1^{\text {st }}$ stage (ISCED 1) and in the Czech Republic, which approved homeschooling three years earlier than Slovakia, there is already undergoing homeschooling of learners at the $2^{\text {nd }}$ stage of primary school (ISCED 2). In Poland, out of all three of the countries under examination, the option of the homeschooling of learners was first introduced into legislation, as early as 1991. Compared to Slovakia and the Czech Republic, homeschooling is currently allowed not only for primary school learners (ISCED 1) or learners at the $2^{\text {nd }}$ stage of primary school (ISCED 2), but it is allowed also for children in nursery schools (ISCED 0), as well as for secondary schools and grammar school students (ISCED 3). Individual (home) education still remains an option for a minority, up to date in concerns about $0,3 \%$ of all learners in Poland, the Czech Republic, and Slovakia, however, the trend is rising (Table 4).

It must be added, in all these countries, homeschooled learners are checked on by the State through the schools they are enrolled in, whether they are fulfilling the obligatory curricula prescribed by the State. While in Slovakia and the Czech Republic it is accomplished twice a year, in Poland it is sufficient only once a year.

It can be proposed that an experimental verification of unschooling should be carried out to clarify, whether unschooling can be implemented under the conditions of the school system in Slovakia, the Czech Republic and Poland. It is also our intention to enlarge this homeschooling research to other European countries and entire world (e.g. Hungary, Ukraine).

\section{Acknowledgements}

This research is published as a part of the GAPF Project No. 6/90/2018 "Individual Education in the V4 Countries - A Comparative Research Study".

\section{References}

Cogan, M. F. (2010). Exploring academic outcomes of homeschooled students. Journal of College Admission, 208, 18-25. Retrieved from https://eric.ed.gov/?id=EJ893891.

Gaither, M. (2008). Homeschool: An American history. New York: Palgrave Macmillan.

Giercarz-Borkowska, M. (2019). Edukacja domowa: Jako alternatywa edukacyjna dla dzieci zdolnych. [Home education: As an educational alternative for talented children]. Wroclaw: Wydawnictwo Teksty.

Gray, P. (2013). Free to learn: Why unleashing the instinct to play will make our children happier, more self-reliant, and better students for life. New York: Basic Books.

Griffith, M. (1997). The homeschooling handbook: From preschool to high school, a parent's guide. Rocklin: Prima Publishing.

Holt, J. (1964). How children fail. Massachusetts: Da Capo Press.

Holt, J. (1967). How children learn. New York: Pitman Publishing.

Holt, J. (2003). Teach your own: The John Holt book of homeschooling. Massachusetts: Da Capo Press.

Illich, I. (2002). De schooling society. London: Marion Boyars.

Kašparová, I. (2012). Children, work and education: First steps to unschooling as a result of current institutional child-care crisis in the Czech Republic. In Proceedings of Belgrade International 
Conference on Education (pp. 31-42). Belegrade, Serbia: Tomorrow People Organization.

Kašparová, I. (2015). Homeschooling: freedom and control in Czech education. Global Dialogue, 5(3), 31-32. Retrieved from http://globaldialogue.isa-sociology.org/homeschooling-freedomand-control-in-czech-education/.

Kostelecká, Y. (2010). Home education in the post-communist countries: Case study of the Czech Republic. International Electronic Journal of Elementary Education, 3(1), 29-44.

Krajčovičová, V., \& Krajčovič, B. (2015). Štatistika žiakov v domácom vzdelávaní v šk. roku 2014/2015. [Statistics of students in home education in the school year 2014/2015]. Home education in Slovakia. Retrieved 13/09/2019, from https://www.domacaskola.sk/statistikaziakov-v-domacom-vzdelavani-v-sk-roku-20142015/?fbclid=IwAR1yWrvyBgde4UC4W9Z GZw7joYvwRCjyyk057dOJNubvoJDiUGg-pAmSC8M.

Moore, R. S., \& Moore, D. N. (1975). Better late than early: A new approach to your child's education. Surry Hills, Australia: Reader's Digest Press.

Murphy, J. (2014). The social and educational outcomes of homeschooling. Sociological Spectrum, 34(3), 1-33. https://doi.org/10.1080/02732173.2014.895640.

Neill, A. S. (1960). Summerhill: A radical approach to child rearing. New York: Hart Publishing.

Ray, B., \& Weller, N. (2003). Homeschooling: An overview and financial implications for public schools. School Business Affairs, 69(5), 22-26.

Rochovská, I., \& Mazur, P. (2019). Theoretical basis of individual (Home) education in Slovakia, the Czech Republic and Poland. Pedagogika.sk. Slovak Journal for Educational Sciences, 10(4), 181-200.

Rousseau, J. J. (1962). Emile, or on education. London \& Toronto: J.M. Dent and Sons.

Ustawa z dnia 14 grudnia 2016 roku - Prawo oświatowe [Act on education system from 14th December 2016]. 2016. (PL).

Zákon o výchove a vzdelávani (školský zákon). [Act on upbringing and education (School Act)]. 2008. (No. 245/2008 Coll.). (SK).

Zákon o předškolním, základním, středním, vyšším odborném a jiném vzdělávání (školský zákon). [Act on pre-school, basic, secondary, tertiary professional and other education (the Education act)]. 2004. (No. 561/2004 Coll.). (CZ).

Received 08 September 2019; accepted 02 December 2019

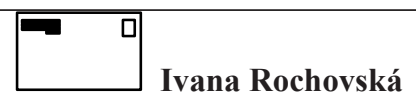

Doc. PaedDr., PhD., Associate Professor, Catholic University in Ruzomberok, Juraj Páleš Institute in Levoča, Bottova 15, 05401 Levoča, Slovakia.

E-mail: ikrupova@gmail.com

\section{Piotr Mazur}

Prof. nadzw., Dr Hab., Associate Professor, the State School of Higher Education in Chelm, ul. Pocztowa 54, 22-100 Chełm, Poland.

E-mail: psmazur@wp.pl

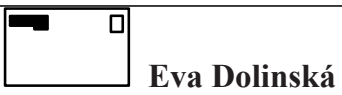

Doc. PaedDr., PhD., Associate Professor, Catholic University in Ruzomberok, Juraj Páleš Institute in Levoča, Bottova 15, 05401 Levoča, Slovakia.

E-mail: edol@centrum.sk 